\title{
sciendo
}

\section{INDIVIDUAL WATER SOURCES AND THEIR POTENTIAL EFFECT ON HUMAN AND ANIMAL HEALTH IN ENVIRONMENTALLY BURDENED REGION}

\author{
Hrušková, T. ${ }^{1}$, Sasáková, N. ${ }^{2}$, Bujdošová, Z. ${ }^{1}$, Sobeková, A. ${ }^{1}$, Šubová, E. ${ }^{2}$ \\ ${ }^{1}$ Department of Chemistry, Biochemistry and Biophysics, Institute of Medical Chemistry \\ ${ }^{2}$ Department of the Environment, Veterinary Legislation and Economy \\ University of Veterinary Medicine and Pharmacy in Košice, Komenského 73, 04181 Košice \\ Slovakia
}

tatiana.hruskova@uvlf.sk

\begin{abstract}
The quality of water in a well that serves as an individual drinking water source, located in the Slovakian region previously burdened with mining activities, was investigated in relation to the quality of surface water in the same region. Selected microbiological and physicochemical parameters were determined in samples of ground water (well) and surface water (brook and river). Plate counts of coliform bacteria, E. coli, enterococci and bacteria cultivated at $22^{\circ} \mathrm{C}$ and $37^{\circ} \mathrm{C}$ were determined. Microbiological quality of samples collected from the well was generally satisfactory. Examination of the samples of surface water (river) showed a significant organic pollution indicated by fluorescence spectra. In all water samples the values of: $\mathrm{pH}$, electrical conductivity, dissolved oxygen, ammonium ions, nitrites, nitrates, chlorides and chemical oxygen demand $\left(\mathrm{COD}_{\mathrm{Mn}}\right)$ were below the limits set by the state legislation. In the surface water, high levels of arsenic were found. The sum of calcium and magnesium in the well water was close to or below the recommended minimum level. In this well water, the
\end{abstract}

level of antimony exceeded 10-fold the maximum limit for drinking water and was of the largest concern as this well water has been used for drinking, cooking, and watering of animals and vegetables for a long period of time. This poses a risk of accumulation of this metalloid in the food chain.

Key words: antimony; arsenic; drinking water; ground water; health risk, surface water

\section{INTRODUCTION}

According to the data published in 2018, approximately $89.25 \%$ of the Slovak population was connected to public water supply [30]. However, the number of inhabitants who disconnect from this public water supply network, primarily for economic reasons, continues to increase. They tend to use water from their own wells as a supplementary source, or prefer bottled water for drinking. In villages not connected to public water supply, people use their own wells, often with water of uncontrolled or unknown quality. Water from 
these individual sources frequently does not meet the quality specified for drinking water by Regulation of the Government of the SR No. 496/2010 Coll., amending and supplementing the SR governmental regulation No. 354/2006 Coll., which determines the requirements on water intended for human consumption and control of water intended for human consumption, hereinafter referred to as the Regulation No. 496/2010 Coll. [38], especially in terms of microbiological indicators which indicate general or faecal pollution. Also, the levels of physico-chemical parameters including heavy metals can exceed the limits set by legislation.

Free-of-charge analysis performed occasionally throughout the Slovak Republic (SR), for example on the occasion of the World Water Day (22 March), is only informative as it focuses mostly on nitrates or nitrites, and does not provide a complex picture about water quality or potential sources of its contamination.

Section 2 of the Regulation No. 496/2010 Coll. [38], defines individual drinking water sources for the purpose of this regulation as sources with daily capacity of less than $10 \mathrm{~m}^{3}$ of drinking water, or supplying water to less than 50 persons. Natural persons or legal entities owning such water sources, pursuant to Section 1, paragraph b), are not classified as persons obliged to fulfil the obligations listed in the Section 3, including the obligation to maintain the prescribed quality of water, ensure disinfection and also inspection thereof.

In our study we focused on the monitoring of the quality of water from a well located near the confluence of a brook and the Ida River in the region of Zlatá Idka village, situated in the Spis-Gemer Ore Mountain (SGOM) area. There are additional wells in this area used as individual drinking water wells. In the region, mining activities were carried out in the past that exploited deposits mainly of heavy metals, such as arsenic (As) and antimony (Sb) $[8,22,24,44]$.

The Ida River, which flows through the location, is one of the tributaries of the Bukovec water-supply reservoir, which serves as one of the drinking water sources for Košice, the regional capital and the second largest city in the SR (population almost 240 000). For this reason, longterm monitoring and regular inspection of the quality of water in this region is performed $[5,22]$.

Levels exceeding the $\mathrm{Sb}$ upper limit value (ULV) $(\mathrm{Sb}=$ $\left.0.005 \mathrm{mg} . \mathrm{l}^{-1}\right)$ were observed, for example, in the Zlatá Idka region, in the Bukovec water-supply reservoir and at other sites [24].
Antimony and arsenic (with atomic numbers 51 for $\mathrm{Sb}$ and 33 for As) are considered metalloids (chemical elements with properties intermediate between those of typical metals and non-metals), elements in the group 15 of the periodic table, and both occur naturally in the environment at trace levels.

Arsenic occurs in nature in approximately 200 rocks, in concentrations below $1-15 \mathrm{mg} \cdot \mathrm{kg}^{-1}$, up to concentrations of $900 \mathrm{mg} \cdot \mathrm{kg}^{-1}$ in case of sedimentary rocks. As levels in surface water in Europe range between 0.1 and $1.7 \mu \mathrm{g} .1^{-1}$, in ground water they are in the range of $0.1-2 \mu \mathrm{g} . \mathrm{l}^{-1}$, while in volcanic rocks the concentrations rise to $3,400 \mu \mathrm{g} \cdot 1^{-1}$, and in the mining areas they reach up to $48,000 \mu \mathrm{g} . \mathrm{l}^{-1}$ in ground water sources [39].

As a recognized human carcinogen causing skin cancer, $\mathrm{As}^{\mathrm{III}}$ is more toxic than $\mathrm{As}^{\mathrm{V}}$. It inhibits biochemical oxidation [1]. Under reduction conditions, it prevails in As ${ }^{\text {III }}$ form; $\mathrm{As}^{\mathrm{V}}$ is an inorganic form predominant under the oxidation conditions in water and soil. Elementary arsenic or $\mathrm{As}^{3-}$ occurs in water very rarely. Organic forms of arsenic are less prevalent in nature than the inorganic ones. Arsenic compounds most frequently occurring in fresh water systems are monomethylarsonic acid (MMA) and dimethylarsinic acid (DMA) [27].

Arsenic is the only contaminant that following exposure through drinking water causes cancer of human skin, lung and bladder, probably also liver; it is also responsible for a range of adverse effects, including hyperkeratosis and peripheral vascular disease $[1,26]$.

Whereas arsenic, a popular poison in ancient history, has absolutely been known as a potentially dangerous element, less is known about antimony; the mechanism of its impact on the environment is not entirely known [53]. $\mathrm{Sb}$ can be released into the environment by natural discharges such as volcanic eruptions, forest fires, or windblown dust. The antimony concentration in air ranges from a nanogram per cubic meter (ng.m ${ }^{-3}$ ) to about $170 \mathrm{ng} . \mathrm{m}^{-3}$ and less than $5 \mathrm{ppb}$ dissolves in lakes or rivers. Antimony is essentially present as pentavalent in fresh and sea water, and as trivalent under anaerobic conditions, as well as a result of anthropogenic activities [47].

Antimony released to the environment will eventually end up in either of the two compartments, soil or sediment, depending on: the release, form of antimony, meteorological conditions, etc. As a constituent of soil, antimony will also be transported into streams and waterways due to 
weathering and run-off from soils; much of this antimony is associated with particulate matter. The absorption of the water soluble compound antimony potassium tartrate following oral intake is approximately $5 \%$ in humans and in experimental animals. The less soluble inorganic antimony compounds are only absorbed to a little extent. Both the absorption of antimony trioxide and the elimination of antimony from blood is a slow process. Antimony is distributed to most tissues with the highest concentrations found in the bone marrow and thyroid gland, followed by spleen, lung, liver, ovaries, heart, kidney, femur and skin. Antimony can also be detected in the testes and brain. The minimal lethal dose for oral intoxication by antimony potassium tartrate has been reported to be $300 \mathrm{mg}$ for a child and $1200 \mathrm{mg}$ for an adult. According to the EU-RAR, no reliable human information regarding the acute toxicity after single oral intake of antimony trioxide is available, and no human data after single dermal exposure to antimony trioxide could be located [6].

Natural organic matter or NOM is a broad term for the complex mixture of thousands of organic compounds found in all surface, ground and soil waters. These compounds are derived from decaying plant and animal matter. $\mathrm{NOM}$ is highly variable and relative concentrations of individual compounds can vary significantly from source to source. For several practical and hygienic reasons, the presence of NOM is undesirable in drinking water [32].

Organic matter in water is composed of two major fractions: dissolved and non-dissolved; defined on the basis of the isolation technique using filters $(0.1-0.7 \mu \mathrm{m})$. Dissolved organic matter (DOM) is the fraction of organic substances that passes the filter. DOM is a heterogeneous mixture of carbon-containing molecules present in all aquatic ecosystems. Globally, DOM plays a key role in carbon and nutrient cycling, and as a substrate for microbial growth, it is one of the main risk factors promoting microbiological growth in distribution networks [7]. DOM optical properties (absorbance and fluorescence) are widely used for studying changes in DOM composition and concentration [33]. Although spectroscopic techniques do not necessarily measure directly the small bioavailable molecules consumed by heterotrophic bacteria, numerous studies have shown that optical measurements are nevertheless sensitive proxies of the wider DOM pool and track subtle changes in water quality. DOM fluorescence is a sensitive tracer of sewage contamination, correlating with
E. coli abundances [3] and nutrients [2] across systems. Excitation-emission matrix (EEM) fluorescence spectroscopy has been widely used to characterize DOM in water and soil [9].

In this study the quality of well water used as an individual drinking water source, located in the Slovakian region previously burdened with mining activities, was investigated together with the quality of surface water in the close vicinity of the well.

\section{MATERIALS AND METHODS}

\section{Sampling sites}

Samples of the ground and surface waters were collected from the region of the village Zlatá Idka, situated in the Spis-Gemer Ore Mountain (SGOM) area in Eastern Slovakia where mining activities were carried out in the past. It is a small village with close to 400 inhabitants. It is connected to the public water supply but not to the public sewer system (installation planned in the years 2021-2027).

Samples of ground water were obtained from a well about $6 \mathrm{~m}$ deep, serving as a drinking water source for two households (W). Water from this well is used for drinking, cooking, personal hygiene, watering livestock and crops.

Samples of surface water were collected at the following sites (Fig. 1):

- from an Idčiansky brook-site A-running at a distance of about 20 meters from the investigated well,

- from the confluence of the brook and the Ida riversite $B$,

- from the Ida river below Zlatá Idka village-site C.

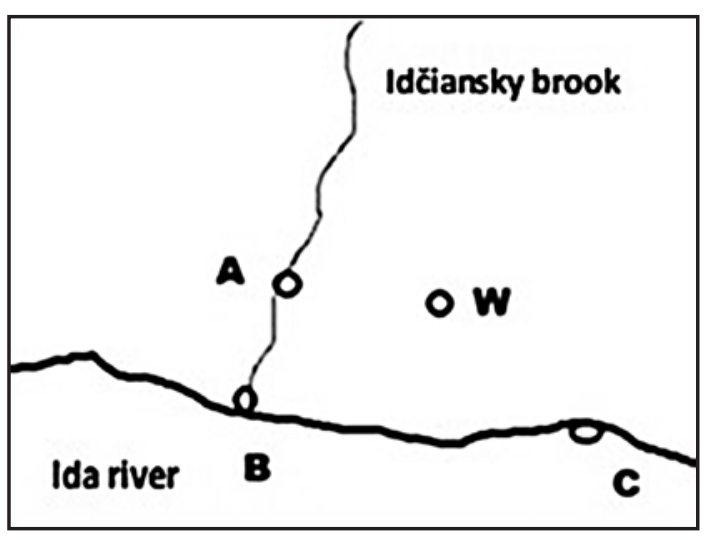

Fig. 1. Ground and surface water sampling sites at Zlatá Idka village A-Idčiansky brook; B-confluence of the Ida river and the brook; CIda river downstream below the village; $\mathrm{W}$-individual water well 
Investigations of the quality of ground and surface water were carried out from October 11, 2016, to March 7 (except February 2017), 2017 in monthly intervals (altogether 5 samplings).

In the samples we determined the selected physico-chemical and microbiological parameters indicating potential and existing contamination of water with faeces. The samples collected at the last sampling in March were examined for arsenic and antimony levels and for obtaining the fluorescence excitation-emission spectra. The results were compared with the limits stipulated by relevant legislation.

\section{Microbiological examination}

Microbiological examinations were carried out according to the Regulation No. 496/2010 Coll. [38]. They included the determination of colony forming units (CFU) of bacteria cultivated at $22^{\circ} \mathrm{C}(\mathrm{BC} 22)$ and $37^{\circ} \mathrm{C}(\mathrm{BC} 37)$, according to the STN EN ISO 6222 [41], coliform bacteria (CB), and E. coli according to the STN EN ISO 9308-1 [46], and enterococci (EC) according to the STN EN ISO 7899-2 [42].

According to the WHO [52], E. coli or thermotolerant coliform bacteria must not be detected in any $100-\mathrm{ml} \mathrm{sam-}$ ple. Also, total coliform bacteria must not be detectable in any $100-\mathrm{ml}$ sample [46].

\section{Physico-chemical examination}

Sensorial evaluation of water (colour, odour, turbidity) was carried out on site and verified in a laboratory after transfer of the samples.

The chemical examination included the determination of electrical conductivity, $\mathrm{pH}$, and saturation with dissolved oxygen. Preliminary qualitative analysis involved the detection of ammonium ions $\left(\mathrm{NH}_{4}^{+}\right)$, nitrites $\left(\mathrm{NO}_{2}^{-}\right)$, nitrates $\left(\mathrm{NO}_{3}^{-}\right)$and chlorides $\left(\mathrm{Cl}^{-}\right)$using colour reactions. If the presence of the tested substance was confirmed, the respective parameter was determined quantitatively. Also, chemical oxygen demand $\left(\mathrm{COD}_{\mathrm{Mn}}\right)$, the sum of the calcium and magnesium $\left(\mathrm{Ca}^{2+}+\mathrm{Mg}^{2+}\right)$ and the levels of arsenic and antimony were determined.

The $\mathrm{pH}$ was determined according to the STN ISO 10523 [45] (pH-meter HACH, WATERPROF pH Tester $30, \mathrm{HACH})$. The conductivity was measured using a conductometer WTW (InoLab Cond 720, Mettler Toledo), according to the manufacturer's instructions.
The quantitative determination of nitrates was carried out directly in samples using an ion-selective nitrate electrode WTW (InoLab pH/ION 735P, Mettler Toledo), according to the manufacturer's instructions. The chlorides were determined by titration according to the STN ISO 9297 [43] by titration. The determinations of $\mathrm{Ca}^{2+}+\mathrm{Mg}^{2+}$ were performed also by titration, according to Horáková [19]. The dissolved oxygen was determined electrochemically using a HACH oxygen probe LDO HQ Series Portable Meters (HACH), according to the manufacturer's instructions and the chemical oxygen demand by oxidation with $\mathrm{KMnO}_{4}$, according to the STN EN ISO 8467 [40].

Arsenic and antimony were determined in samples collected in March by a specialized water laboratory of the East Slovak Water Company, workplace Kokšov-Bakša [44].

\section{Fluorescence Excitation Emission Matrix (EEM) spectroscopy}

Fluorescence spectroscopy is a highly sensitive technique that can be used to characterize organic matter in water sources through three-dimensional spectra called excitation-emission matrices (EEM). This method was used to examine samples collected in March. To obtain the EEM spectra the samples were examined under a luminescence spectrophotometer Perkin Elmer LS 55 (Medical and Clinical Biochemistry Institute and LABMED, Inc., USA) at the Faculty of Medicine, Pavol Jozef Šafárik University in Košice (Slovakia), using the following settings: excitation wavelength $250-450 \mathrm{~nm}$ with gradual $10 \mathrm{~nm}$ increment increase, range $\lambda=250-600 \mathrm{~nm}$ (excitation/emission slit: $5 / 10 \mathrm{~nm}$, quartz cuvette of width $1 \mathrm{~cm}$, emission monochromator scanning rate: $20 \mathrm{~nm} \cdot \mathrm{s}^{-1}$ ). The EEM were obtained using a FIW Inlab software [11].

\section{Statistical analysis}

The results of the physico-chemical examinations are presented as the means \pm SD of five samplings at the following sites: Idčiansky brook (A), confluence of river and brook (B), end of the village (C) and individual water well (W). The statistical analysis was carried out by the one-way analysis of variance (ANOVA) using post hoc Tukey multiple comparison test (the Prism 3 software). The differences at the level of $\mathrm{P}<0.05$ were considered significant. 


\section{RESULTS}

\section{Physico-chemical parameters}

\section{Ground water}

The results of the physical examinations complied with the legislative requirements. The presence of $\mathrm{NH}_{4}^{+}$ions was detected qualitatively only in one sample of well water collected on October 11, 2016. The quantitative determinations showed that its level at this sampling reached $1.9 \mathrm{mg} . \mathrm{l}^{-1}$ (limit $0.5 \mathrm{mg} \cdot \mathrm{l}^{-1}$ ). All other samples provided negative results. The presence of $\mathrm{NO}_{2}^{-}$ions was not detected at any sampling. The upper limits for $\mathrm{NO}_{3}^{-}, \mathrm{COD}-$ $\mathrm{Mn}$ and $\mathrm{Cl}^{-}$were not exceeded. The contents of calcium and magnesium were close to or below the recommended range of $0.55-1.55$ samplings (Table 1 ). The level of arsenic in the well was below the statutory limit. However, it was alarming that the value of the antimony concentration was 10 -fold higher than the permitted value for drinking water (Table 2).

\section{Surface water}

The chemical examinations of the surface water indicated good quality of water at all sampling sites with the exception of arsenic and antimony. The levels of arsenic in surface water samples ranged between 17 and $28.5 \mu \mathrm{g} . \mathrm{l}^{-1}$, which classified them as the A2 category of water quali-

Table 1. Results of physico-chemical examination of surface and ground (well) water

\begin{tabular}{|c|c|c|c|c|c|c|}
\hline Parameters & A & B & C & $\begin{array}{c}\text { Limits }^{2} \\
\text { Surface water } \\
(\mathrm{OH}-\mathrm{MH})\end{array}$ & W & $\begin{array}{l}\text { Limits }^{3} \\
\text { Ground water }\end{array}$ \\
\hline pH & $6.8 \pm 1.2$ & $6.6 \pm 1.3$ & $6.5 \pm 1.3$ & $6.5-8.5(\mathrm{~A} 1)$ & $7.2 \pm 0.8$ & $6.5-9.5$ \\
\hline $\begin{array}{l}\mathrm{O}_{2} \text { saturation } \\
{[\%]}\end{array}$ & $88.8 \pm 6.8$ & $93.6 \pm 5.8$ & $93.9 \pm 4.9$ & $<80(\mathrm{~A} 1)$ & $74.3 \pm 11.6$ & $>50$ \\
\hline $\begin{array}{l}\text { Conductivity } \\
{\left[\mathrm{mS}^{\left.-\mathrm{m}^{-1}\right]}\right.}\end{array}$ & $19.9 \pm 5.6$ & $14.8 \pm 3.6$ & $14.7 \pm 3.0$ & $100(\mathrm{~A} 1)$ & $25.2 \pm 2.2$ & 125 \\
\hline $\begin{array}{l}\mathrm{Cl}^{-} \\
{\left[\mathrm{mg} . .^{-1}\right]}\end{array}$ & $7.8 \pm 5.2$ & $8.2 \pm 3.7$ & $8.2 \pm 4.5$ & $100 \mathrm{~A} 1$ & $7.6 \pm 3.4$ & 250 \\
\hline $\begin{array}{l}\mathrm{NO}_{3}^{-} \\
{\left[\mathrm{mg} . .^{-1}\right]}\end{array}$ & $11.8 \pm 9.6$ & $13.5 \pm 10.4$ & $14.7 \pm 11.3$ & 7-11' (A3) & $11.8 \pm 3.8$ & 50 \\
\hline $\begin{array}{l}\mathrm{COD}_{\mathrm{Mn}} \\
{\left[\mathrm{mg} . \mathrm{I}^{-1}\right]}\end{array}$ & $0.7 \pm 0.6$ & $1.9 \pm 1.9$ & $1.4 \pm 0.8$ & $2.0(\mathrm{~A} 1)$ & $0.4 \pm 0.1$ & 3 \\
\hline $\begin{array}{l}\mathrm{Ca}^{2+}+\mathbf{M g}^{2+} \\
{\left[\mathrm{mmol} . .^{-1}\right]}\end{array}$ & $0.8 \pm 0.4$ & $0.8 \pm 0.3$ & $0.8 \pm 0.3$ & - & $0.9 \pm 0.4$ & $1.1-5$ \\
\hline
\end{tabular}

Results are expressed as means \pm standard deviation $(n=5)$; differences in the levels of parameters $A, B$ and $C$ were insignificant; Sampling sites: A-Idčiansky brook; B-river and brook confluence; C-Ida river below the village; W-individual source of drinking water (well); $\mathrm{OH}$-recommended limit value of the indicator; $\mathrm{MH}$ - limit value of the indicator; ${ }^{1}$ The concentration values for these characteristics need not to be complied with if justified by geographical or climatic conditions; ${ }^{2}$ Limits stipulated by the Regulation No. 269/2010 Coll. [37] Category A1-water requiring simple physical treatment and disinfection, or rapid filtration and disinfection; Category A3-water requiring intensive physico-chemical treatment and disinfection such as coagulation, flocculation, filtration, activated carbon adsorption, chlorine or ozone disinfection, critical point chlorination and decantation; ${ }^{3}$ Limits stipulated by the Regulation No. 496/2010 Coll. [38]

Table 2. Arsenic and antimony levels determined in surface and ground (well) water

\begin{tabular}{lccccccc}
\hline Parameters & A & B & C & $\begin{array}{c}\text { Regulation } \\
\text { No. 269/2010 } \\
\text { A2 category }\end{array}$ & $\begin{array}{c}\text { Regulation } \\
\text { No. 269/2010 } \\
\text { A3 category }\end{array}$ & W & $\begin{array}{l}\text { Regulation } \\
\text { No. 496/2010 }\end{array}$ \\
\hline As $\left[\mu \mathrm{g} . \mathrm{I}^{-1}\right]$ & 28.5 & 21.8 & 17 & $20-50$ & $50-100$ & $0.005 \mathrm{mg}^{-\mathrm{I}^{-1}}$ & $0.01 \mathrm{mg}^{\mathrm{I}^{-1}}$ \\
$\mathrm{Sb}\left[\mathrm{mg} . \mathrm{I}^{-1}\right]$ & 0.0827 & 0.0657 & 0.0517 & $0.01-0.025$ & $>0.025$ & 0.05 & 0.005 \\
\hline
\end{tabular}

Sampling sites: A-Idčiansky brook; B-river and brook confluence; C-Ida river below the village; W-individual source of drinking water (well); 269/2010 - limits for A1 and A2 categories of surface water stipulated by the Regulation No. 269/2010 Coll. [37]; 496/2010 -limits for ground water stipulated by the Regulation No. 496/2010 Coll. [38]; Category A2-water requiring physico-chemical treatment and disinfection such as coagulation, flocculation, filtration, chlorine disinfection, pre-chlorination and decantation; Category A3-water requiring intensive physico-chemical treatment and disinfection such as coagulation, flocculation, filtration, activated carbon adsorption, chlorine or ozone disinfection, critical point chlorination and decantation 
ty, according to the Annex No. 2, section A: Surface Water Intended for the Supply of Drinking Water, of the Regulation of the Government of the SR No. 269/2010 Coll., hereinafter referred to as Regulation No. 269/2010 Coll. [37]. Due to antimony, determined in March in concentrations ranging between 0.0517 and $0.0827 \mathrm{mg}^{-\mathrm{l}^{-1}}$, the water quality was classified as the worst A3 category of the aforesaid standard. In both cases, the highest concentrations of the monitored metalloids were observed at the confluence of the river and the brook, the sampling site B (Table 2).

\section{Microbiological parameters}

Microbiological results obtained by examination of samples of water from the well and the surface water differed considerably.

\section{Ground water}

The microbiological quality of water in the well (W) was very good as no E. coli or enterococci were detected in the $10 \mathrm{ml}$ samples. The total coliform bacteria were presented in this water only at the fourth sampling in January (3 CFU.10 ml-1). According to the Regulation No. 496/2010 Coll. they should not be detected in any $10 \mathrm{ml}$ of well water intended for individual supply (max. 50 people). Also, the levels of bacteria cultivated at $22^{\circ} \mathrm{C}\left(0-52 \mathrm{CFU} .1 \mathrm{ml}^{-1}\right.$; limit 500 CFU. $1 \mathrm{ml}^{-1}$ ) and $37^{\circ} \mathrm{C} \mathrm{(5-20} \mathrm{CFU.1} \mathrm{ml-1} \mathrm{lim-}$ it 100 CFU. $1 \mathrm{ml}^{-1}$ ) complied with the statutory limits for drinking water.

\section{Surface water}

Results obtained by the microbiological examinations of the surface water in the investigated area (A, B, C) are presented in Table 3.

Investigations of water from the Idčiansky brook (A), river and brook confluence (B), and the river below the village $(\mathrm{C})$, revealed considerable variations between the sampling sites, individual parameters, and samples collected at the individual samplings. With regard to the $\mathrm{CB}$, E. coli and EC which represented the indicators of faecal pollution of water, the highest contamination was detected at site B. Most of the results indicated that at this site the levels of these three parameters exceeded the limits or recommendations of $\mathrm{A} 2$, even of the A3 categories. Especially the counts of enterococci (faecal streptococci) at this site were extremely high at all samplings indicating not only potential risk, but the real presence of animal or human faeces. Overall, samples collected at all three sampling sites classified the water in the worst quality category of A3, as specified in the Annex No. 2 of the Regulation No. 269/2010 Coll., section A [37].

Table 3. Results of microbiological examination of surface water

\begin{tabular}{|c|c|c|c|c|c|c|c|c|}
\hline \multirow{2}{*}{ Parameter } & \multicolumn{3}{|c|}{ Limits for categories [37] } & \multicolumn{5}{|c|}{ Samplings } \\
\hline & A1 & A2 & A3 & 1 & 2 & 3 & 4 & 5 \\
\hline $\begin{array}{l}\text { CB } \\
\text { CFU/100 ml }\end{array}$ & 50 & 5000 & 50000 & $\begin{array}{l}\text { A: } 17000 \\
\text { B: } 67000 \\
C: 28000\end{array}$ & $\begin{array}{l}\text { A: } 4000 \\
B: 12000 \\
C: 3000\end{array}$ & $\begin{array}{c}\text { A: } 8000 \\
\text { B: } 8000 \\
C: 22000\end{array}$ & $\begin{array}{c}\text { A: } 6000 \\
\text { B: } 0 \\
C: 9000\end{array}$ & $\begin{array}{l}\text { A: } 2000 \\
\text { B: } 10000 \\
\text { C: } 5000\end{array}$ \\
\hline $\begin{array}{l}\text { E. coli } \\
\text { CFU/100 ml }\end{array}$ & 0 & $10^{*}$ & $100^{*}$ & $\begin{array}{l}\text { A: } 1000 \\
\text { B: } 5000 \\
C: 2000\end{array}$ & $\begin{array}{l}A: 0 \\
B: 0 \\
C: 0\end{array}$ & $\begin{array}{c}\text { A: } 0 \\
\text { B: } 7000 \\
\text { C: } 5000\end{array}$ & $\begin{array}{c}\text { A: } 2000 \\
\text { B: } 0 \\
C: 5000\end{array}$ & $\begin{array}{c}\text { A: } 0 \\
B: 7000 \\
C: 2000\end{array}$ \\
\hline $\begin{array}{l}\text { EC } \\
\text { CFU/100 ml }\end{array}$ & 300 & $1000^{*}$ & $1000^{*}$ & $\begin{array}{l}A: 12000 \\
B: 19000 \\
C: 3000\end{array}$ & $\begin{array}{c}\text { A: } 0 \\
B: 48000 \\
C: 58000\end{array}$ & $\begin{array}{l}A: 2000 \\
B: 7000 \\
C: 11000\end{array}$ & $\begin{array}{c}\text { A: } 0 \\
\text { B: } 13000 \\
C: 45000\end{array}$ & $\begin{array}{l}A: 2000 \\
B: 7000 \\
C: 2000\end{array}$ \\
\hline $\begin{array}{l}\text { CB22 } \\
\text { CFU/1 ml }\end{array}$ & 100 & 100 & 100 & $\begin{array}{l}\text { A: } 0 \\
\text { B: } 0 \\
\text { C: } 0\end{array}$ & $\begin{array}{c}\text { A: } 580 \\
\text { B: } 650 \\
C: 18800\end{array}$ & $\begin{array}{l}A: 0 \\
B: 0 \\
C: 0\end{array}$ & $\begin{array}{c}A: 0 \\
B: 0 \\
C: 100\end{array}$ & $\begin{array}{l}A: 0 \\
B: 0 \\
C: 0\end{array}$ \\
\hline $\begin{array}{l}\text { CB36 } \\
\text { CFU/1ml }\end{array}$ & 20 & $200^{*}$ & $1000^{*}$ & $\begin{array}{c}A: 340 \\
B: N C \\
C: 3400\end{array}$ & $\begin{array}{c}A: 70 \\
B: 450 \\
C: 6600\end{array}$ & $\begin{array}{c}\text { A: } 60 \\
\text { B: } 80 \\
\text { C: } 10400\end{array}$ & $\begin{array}{c}\text { A: } 140 \\
\text { B: } 10 \\
C: 4800\end{array}$ & $\begin{array}{l}A: 20 \\
B: 80 \\
C: 60\end{array}$ \\
\hline
\end{tabular}

$\mathrm{CB}$-coliform bacteria: $\mathrm{EC}$-enterococci; $\mathrm{CB} 22$-bacteria cultivated at $22^{\circ} \mathrm{C} ; \mathrm{CB} 36$-bacteria cultivated at $36^{\circ} \mathrm{C} ; \mathrm{NC}$-non-countable; Sampling sites: A-Idčiansky brook; $B$ - confluence of Ida river and the brook; $C$-Ida river below the village; Limits and categories are specified in the Regulation No. 496/2010 Coll.; ${ }^{*}$-levels recommended by [37] for parameters for which no limits are stipulated 


\section{EEM spectroscopy}

The unfavourable microbiological results indicated considerable organic pollution of the examined surface water that was also confirmed by the fluorescence spectra (Fig. 3).

Water from the well and from the brook (A) did not show any significant differences; in addition to humic substances, there were also detected bioorganic degradable substances (proteins).

The samples of water from the Ida River at both sampling sites, B and C, showed a high content of humic substances and pollution by bioorganic products, proteins and sewage residuals.

All four samples were qualitatively similar and differed only in the intensity of pollution or the concentration of organic substances (from the lowest to the highest):

- Humic substances and humic acids: the well and the brook provided almost identical results; the Ida River at the confluence and the Ida River behind the village showed the highest values;

- Proteins: brook; well, the Ida River behind the village; the Ida River at the confluence showed the highest values;
- Complexes of proteins and humic substances: well, brook values were almost identical; the Ida River behind the village; the Ida River at the confluence showed the highest values;

- Sewage: the Ida River at the confluence.

All samples showed significant similarities as they came from the same, significantly polluted location.

\section{DISCUSSION}

Our investigations of ground water in the region polluted by previous mining activities exploiting deposits mainly of heavy metals showed that with regard to selected chemical parameters (Table 1), excluding As and Sb, the water corresponded to drinking water quality with the exception of $\mathrm{NH}_{4}{ }^{+}$ions at one sampling (October). The presence of these ions that indicate fresh pollution with animal or human wastes can be related to a single pollution incident, for example intensive precipitation and/or application of manure. The good quality of surface water, for example high $\mathrm{O}_{2}$ saturation and low levels of chlorides and nitrates may be related to the colder season of the year with limited agri-

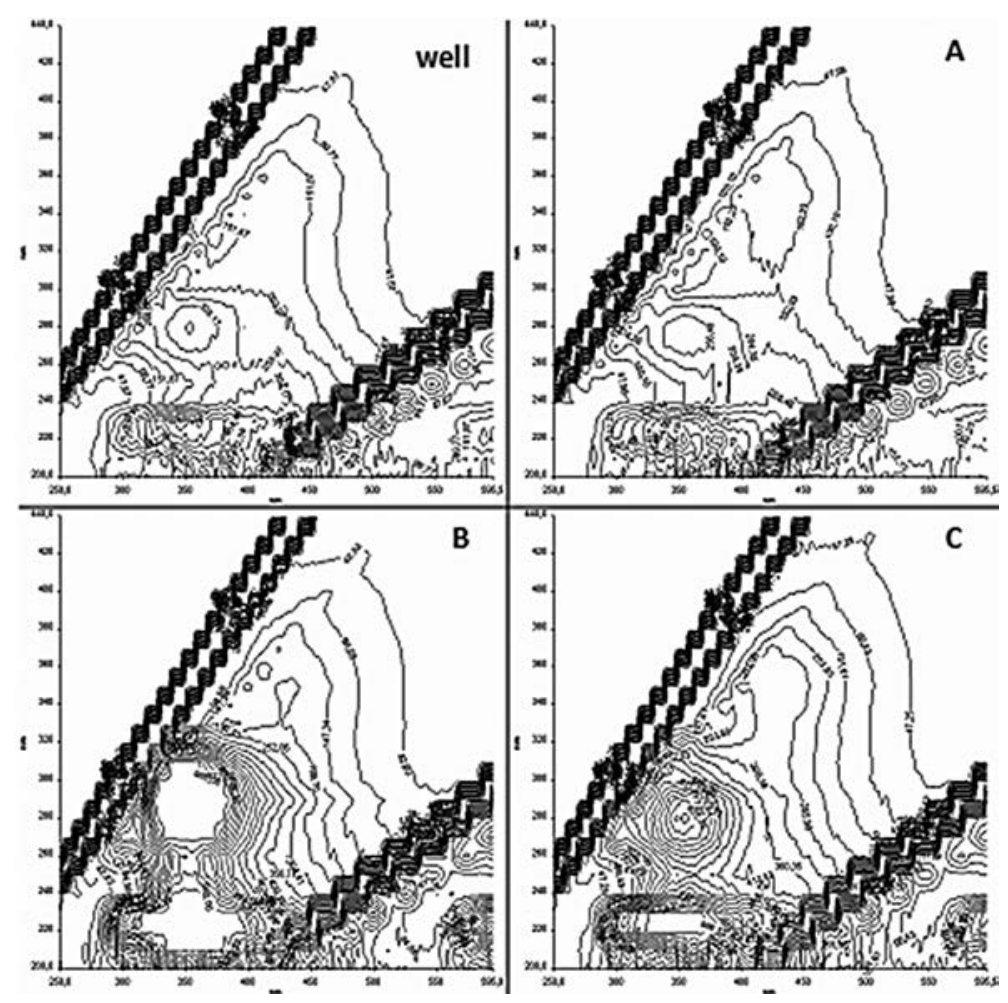

Fig. 3. Fluorescence spectra of the well and surface waters A, B, C

A-Idčiansky brook; B-river and brook confluence; $\mathrm{C}$-Ida river below the village 
cultural activities that could affect the investigated parameters. Although the content of $\mathrm{Ca}$ and $\mathrm{Mg}$ was very close to the lowest acceptable limit, even a little below it, no significant health effects of such levels have been confirmed.

Our microbiological examinations of the ground water provided very good results as no E. coli or enterococci were detected in $10 \mathrm{ml}$ samples. The total coliform bacteria were detected only at the fourth sampling in January (3 CFU.10 ml-1) indicating the possibility of some accidental contamination. Also, the levels of bacteria cultivated at $22{ }^{\circ} \mathrm{C}\left(0-52\right.$ CFU. $1 \mathrm{ml}^{-1}$; limit $\left.500 \mathrm{CFU} .1 \mathrm{ml}^{-1}\right)$ and $37^{\circ} \mathrm{C}$ (5-20 CFU.1 ml-1; limit 100 CFU.1 $\mathrm{ml}^{-1}$ ) indicated that the general pollution complied with the statutory limits for drinking water. The well was covered and no immediate source of pollution was present, except for the Idčiansky brook at about $20 \mathrm{~m}$ distance from the well. Although the well was not very deep $(6 \mathrm{~m})$, evidently the soil filtration capacity was sufficient to cope with most of the potential contamination.

However, the limit for antimony in the drinking water was exceeded 10-fold in this well which poses a health risk to humans and other animals, especially at long-term consumption of such water as discussed below.

The determined chemical parameters indicated a good quality of surface water at all sampling sites with the exception of arsenic and antimony. The level of arsenic in surface water $\left(17-28.5 \mu \mathrm{g} . \mathrm{l}^{-1}\right)$ classified it as the A2 category of water quality. However, antimony concentrations ranging between 0.0517 and $0.0827 \mathrm{mg} . \mathrm{l}^{-1}$, which classified this water as the worst A3 category. The highest concentrations of the metalloids were detected at the confluence of the Ida River and the Idčiansky brook at the sampling site B (Table 2).

The samples collected at the site B showed also the highest contamination with $\mathrm{CB}$, E. coli and EC that represent the indicators of faecal pollution. Most of the results at this site exceeded the limits or recommendations of A2; even of A3 categories. Especially the counts of enterococci (faecal streptococci) at this site were extremely high at all samplings indicating not only the potential risk but the real presence of animal or human faeces. Overall, samples collected at all three sampling sites classified the water in the worst quality category A3. The unfavourable microbiological results indicated considerable organic pollution of the examined surface water that was also confirmed by the fluorescence spectra (Fig. 3). The Idčiansky brook and the
Ida river flow through the village of Zlatá Idka and the absence of public sewer system evidently contributes to the poor quality of water in this region.

The humic acids and proteins in the water confirmed by the fluorescence spectra may play a role also in the content and interactions of metalloids in the water.

The interaction with humic acids can be described as the adsorption of $\mathrm{Sb}^{\mathrm{III}}$ by humic acids and it is governed by the Langmuir isotherm. The extent of the $\mathrm{Sb}^{\mathrm{V}}$ bond to organic mass has not been clarified. However, it was proved that the antimonic acid forms complexes with functional groups containing oxygen, where the complexation takes place in humic substances. The interactions of $\mathrm{Sb}$ with a solid stage indicate that antimony is present in the solution [51].

Binding is significant at acidic $\mathrm{pH}$ for $\mathrm{Sb}^{\mathrm{III}}$ and $\mathrm{Sb}^{\mathrm{V}}$, but in the case of $\mathrm{Sb}^{\mathrm{v}}$, it decreases above $\mathrm{pH} 6-8$. The adsorption of antimony by iron oxides in acidic media takes the shape of forming Fe-O-Sb bonds. Natural organic matter (NOM) can bind metal ions and accelerate antimony redox reactions in aqueous systems $[13,14,18]$.

There are 9 deposits of antimony ores in the Slovak territory (Little Carpathians, Low Tatras, Spiš-Gemer Ore Mountains), which served as important antimony sources in Europe, until the mining was discontinued in 1991.

The research project "Estimation of Health Risk from Arsenic and Antimony Presented in the Environment of Zlatá Idka Village", sponsored by the State Health Institute in Košice, carried out in the period 2000-2004 in the surrounding area of Zlatá Idka (SGOM) focused on health risks of the long-term impact of As and $\mathrm{Sb}$ accumulation, revealed that the contents of these metalloids observed in mining and surface waters exceeded the statutory limits. In the surface flow of the Ida River below the Zlatá Idka village, the content of As reached 32 to $34 \mu \mathrm{g} .1^{-1}$ and levels of $\mathrm{Sb}$ were 0.055 to $0.065 \mathrm{mg} . \mathrm{l}^{-1}$, exceeding the limits permitted by the Regulation No. 269/2010 Coll. [37]. Human samples (urine, blood, hair) showed excessive values of As and $\mathrm{Sb}$ concentrations, especially in inhabitants from the area of Zlatá Idka village (SGOM) $[35,36]$. The As and Sb concentrations determined in the blood $\left(16.3 \mu \mathrm{g} . \mathrm{l}^{-1}\right.$ and $\left.3.8 \mu \mathrm{g} . \mathrm{l}^{-1}\right)$, urine $\left(15.8 \mu \mathrm{g} . \mathrm{l}^{-1}\right.$ and $\left.18.8 \mu \mathrm{g} . \mathrm{l}^{-1}\right)$, nails $(3.179 \mu \mathrm{g}$. $\mathrm{kg}^{-1}$ and $\left.1.140 \mu \mathrm{g} \cdot \mathrm{kg}^{-1}\right)$ and hair $\left(379 \mu \mathrm{g} . \mathrm{kg}^{-1}\right.$ and $357 \mu \mathrm{g}$. $\mathrm{kg}^{-1}$ ) were higher than values of people from non-contaminated areas. Health risk calculations for the ingestion of soil, water, and vegetables indicate a very high carcinogenic 
risk (>1/1.000), as for the content in soil and water [34]. The studies by $\mathrm{R}$ a p a $\mathrm{n} \mathrm{t}$ et al. $[35,36]$ revealed different causes of death in Zlatá Idka than in other villages of the region. People from this village suffered more frequently from different diseases, mainly diabetes, due to the negative impact of $\mathrm{Sb}$ on the glucose level in blood. Also there was observed an increased number of mental disorders and cancer, the latter attributed mostly to As.

The Council of the European Communities established the value of $5.0 \mu \mathrm{g} .1^{-1}[10]$ as the highest permitted level for antimony in water intended for human consumption (this Directive has been incorporated into the respective regulations of the EU member states). On the other hand, the U. S. Environmental Protection Agency (USEPA) suggested a maximum antimony concentration of $6 \mu \mathrm{g} . \mathrm{l}^{-1}$ in drinking water [49].

For a long periods of time, a drinking water supplier operating in the region has been dealing with the increased concentration of As and especially $\mathrm{Sb}$, applying modern technologies based on iron-based sorption materials, to achieve the required quality of water $[24,48]$. Despite the availability of the existing drinking water source, the public water-supply network, many households have not connected thereto and use their own wells as a drinking water source, without having the quality of water from their source inspected.

In Slovakia, there are a number of locations of antimony mineralization with possible occurrence of gold ore, for example in the Spiš-Gemer Ore Mountain (Betliar, Čučma and Poproč). However, according to the results of the survey carried out in 1977-1983, they did not reach the deposit parameters. Similar economic insignificance was observed for antimony occurrence in the regions of Kremnica and Zlatá Baňa $[4,20]$.

The high concentrations of antimony and arsenic in the environment have been detected not only in Slovakia, but all over the world. The impact of these individual metalloids on the environment, as well as their presence in the food chain and impact on human and other animal health present a global problem without frontiers.

In Greece, the results of groundwater analyses from the region of Eastern Thessaly indicated elevated concentrations of $\mathrm{As}$ and $\mathrm{Sb}$ due to the presence of the arsenopyrite and stibnite in the Melivoia, Sotiritsa and Ano Polydendri areas. Both of them, with similar geochemical behaviour in the environment, are noted for formation of complexes.
According to K e le per t s is et al. [25] about 5,000 people in the mentioned area drink water containing As and $\mathrm{Sb}$ above the values defined by the EC and US EPA guidelines.

Antimony, with the most common forms of $\mathrm{Sb}$ ore in nature, such as $\mathrm{Sb}_{2} \mathrm{~S}_{3}$ (stibnite, antimonite), is the only form of $\mathrm{Sb}$ ore mineral in the world's largest $\mathrm{Sb}$ ore depositXikuangshan, China $[16,31]$. In the same area, the heavy contamination ( $\mathrm{Sb}, \mathrm{As}, \mathrm{Cd}$, and $\mathrm{Hg}$ ) in the soil profiles was mostly located in the uppermost soil layers enriched in organic matter (depth $40 \mathrm{~cm}$ ) and exhibited downward migration in the soil profiles. Sb and As showed significant mobility in the profiles $[21,50,55]$.

The results of $\mathrm{Li}$ et al. [28, 29] established the importance of considering the bioaccessible $\mathrm{Sb}$ and As data rather than the total content for health risk calculations, because it could provide more realistic estimations of the health risks posed by the $\mathrm{Sb}$ and As contamination.

$\mathrm{Fu}$ et al. [17] and Y a ng et al. [56] studied the impact of bioaccumulation of $\mathrm{As}, \mathrm{Sb}$ and $\mathrm{Hg}$ in a large $\mathrm{Sb}$ mining/smelting area in Hunan, China, that had been seriously polluted by $\mathrm{Sb}$. Water from the reservoirs and river near the $\mathrm{Sb}$ mine area was not suitable for use as drinking water because of high $\mathrm{Sb}$ concentration, seriously exceeding the Chinese guideline for drinking water. However, it has not been proved so far, whether the co-exposure to As and $\mathrm{Sb}$ has a synergistic effect on human health [54].

In the past decades, it was observed that the cancer risk was higher among people who were regularly exposed to high environmental arsenic concentrations. UNICEF estimates that in Vietnam there are approximately 10-15 million of the people (about $13.5 \%$ of the population) using drinking water from tube wells, the arsenic concentrations of which ranged from 8-579 ppb (mean $301 \mathrm{ppb}$ ) [23].

According to Etim [12] there is a health risk due to increased occurrence of arsenic, antimony and selenium in shallow groundwater systems of Ibadan Metropolis (Southwestern Nigeria) caused by its significantly higher levels with $100 \%$ of examined samples exceeding the WHO safe limits.

While the Environmental Protection Agency (EPA) allows 0.006 parts of antimony per million parts of drinking water, the guidelines for Drinking-water Quality [49], WHO established a tolerable daily intake (TDI) of $6 \mu \mathrm{g} . \mathrm{kg}^{-1}$ body weight/day for antimony $[52,53]$, and the limit for $\mathrm{Sb}$ in drinking water, pursuant to the applicable laws in the $\mathrm{SR}$, is $0.05 \mathrm{mg} . \mathrm{l}^{-1}$. 
With regard to constantly rising concentration of $\mathrm{Sb}$ in the environment, it is inevitable to pay urgent attention to the research of its bioaccumulation and the examination of $\mathrm{Sb}$ migration and integration in the food chain and, subsequently, biological effects thereof. So far, the information about antimony, with regard to the risk to human health from the accumulation thereof, is insufficient and the existing studies indicate that increased concentrations of antimony present a global problem, as it evidently causes diseases of the liver, skin, and the cardiovascular system [6, $12,13,15,17,26,54]$.

The fluorescence spectra obtained in our study indicated high organic pollution (DOM) of the river, while those of the well and brook water showed almost identical level of humic substances and bioorganic degradable substances but lower than those found in the river water.

$\mathrm{Zh}$ ang et al. [57] used UV-vis and fluorescence (EEM) spectroscopy to investigate the characteristics of DOM in river flowing into a key drinking water source in China and reported that they had a profound influence on the quality and safety of water. They detected spatiotemporal variations of spectral characteristics on DOM. Their concentration was much higher in the wet season and the data provided technical support for improving the quality and comprehensive treatment of drinking water sources.

In addition to the above discussed and historically known possibilities of geogenic burden, that affects the quality of drinking water sources, there are also sources primarily anthropogenic, for which it is difficult to estimate their impact on the quality of water, and they definitely require regular inspections. Every source of drinking water intended for long-term use regardless of the daily consumption or the source size must not represent any hazard to health. On the contrary, its composition should have a positive impact on health and represent a safe choice how to adhere to the drinking regime as an essential part of a healthy lifestyle of each individual.

In addition to the discussed area of the Zlatá Idka village, there are many other locations where wells are used as sources of drinking water, with quality of water not necessarily complying with the drinking water criteria.

\section{CONCLUSIONS}

In many areas burdened with industrial and agricultural production, the individual water sources, serving primarily as sources of drinking water as well as water for watering of animals and plants, can be significantly contaminated by secondary products or biological waste. According to the results of our study concerning the quality of ground water in the investigated area, the level of antimony was of the greatest concern. It was also very high in the surface water. As the drinking water used on a daily basis must not represent any hazard to health due to longterm consumption of xenobiotics or other life endangering contaminants, it is very important to ensure adequate protection and carry out regular inspection and disinfection of all individual sources of drinking water. It would be appropriate to consider potential modifications of the legislation with the aim to ensure verification of the quality of each individual source intended for the long-term use as a source of drinking water for humans and farm animals.

\section{ACKNOWLEDGEMENT}

This study was supported by the project of the SR Science Grant Agency (VEGA) No. 2/0125/17.

\section{REFERENCES}

1. Ahmad, A., Haque Khan, M., Haque, M., 2018: Arsenic contamination in groundwater in Bangladesh: implications and challenges for healthcare policy. Risk Manag. Health Policy, 11, 251-261. DOI: 10.2147/RMHP.S153188.

2. Baker, A., Inverarity, R., 2004: Protein-like fluorescence intensity as a possible tool for determining river water quality. Hydrol. Process, 18, 15, 2927-2945. DOI: 10.1002/hyp.5597.

3. Baker, A., Cumberland, S. A., Bradley, C., Buckley, C., Bridgeman, J., 2015: To what extent can portable fluorescence spectroscopy be used in the real-time assessment of microbial water quality? Sci. Total Environ, 532, 14-19. DOI: 10.1016/j.scitotenv.2015.05.114.

4. Baláž, P., Kúšik, D., 2008: Minerals of the Slovak Republic: Interim Report (In Slovak). The State Institute of Geology of Dionýz Štúr, Spišská Nová Ves, Bratislava, 163 pp.

5. Barloková, D., Ilavský. J., Kunštek, M., 2012: Removal of 
antimony from water by coagulation. Food Environ. Safety J., $11,10-18$.

6. Bredsdorff, L., Nielsen, E., 2015: Antimony: Evaluation of Health Hazards and Proposal of a Health Based Quality Criterion for Soil. Danish Environmental Protection Agency, Copenhagen, Denmark, 39 pp.

7. Camper, A. K., Brastrup, K., Sandvig, A., Clement, J., Spencer, C., Capuzzi, A. J., 2003: Effect of distribution system material on bacterial regrowth. J. Am. Water Works Assoc., 95, 7, 107-121. DOI: 10.1002/j.1551-8833.2003.tb10412.x.

8. Cech, E., Michaeli, E., Krokusova, J., Ivanova, M., 2015: Contamination of Selected Components of the Environment in the Middle Spiš Region (Slovak Republic). Int. Sci. Conf. GEOBALCANICA 2015, 43-49. DOI: 10.18509/ GBP.2015.06.

9. Chen, W., Westerhoff, P., Leenheer, A. J., Booksh, K., 2003: Fluorescence excitation-emission matrix regional integration to quantify spectra for dissolved organic matter. Environ. Sci. Tech., 37, 5701-5710. DOI: 10.1021/es034354c.

10. Council Directive 98/83/EC of November 3, 1998, on the quality of water intended for human consumption. https:// eur-lex.europa.eu/legal-content/EN/TXT/?uri=CELEX:01998L0083-20151027.

11. Dubayová, K., Tichá, M., Kušnír, J., Lučková, I., Rigdová, K., Gondová, T., 2008: The fluorescence contour map as "identity card" of spring waters. The use of chemical methods in protecting and promoting public health (In Slovak). Programme and Book of abstracts, 9-10 Sept., Košice, 13.

12. Etim, E. U., 2018: Occurrence and distribution of arsenic, antimony and selenium in shallow groundwater systems of Ibadan metropolis, Southwestern Nigeria. J. Health Poll., 13, 32-41.

13. Filella, M., Williams, P. A., Belzile, N., 2009: Antimony in the environment: knowns and unknowns. Environ. Chem., 6, 95-105. DOI: 10.1071/EN09007.

14. Filella, M., 2011: Antimony interactions with heterogeneous complexants in waters, sediments and soils: A review of data obtained in bulk samples. Earth-Sci. Rev., 107, 325-341.

15. Filella, M., Williams, P. A., 2012: Antimony interactions with heterogeneous complexants in waters, sediments and soils: A review of binding data for homologous compounds. Chem. Erde, 72, S4, 49-65.

16. Fu, Z., Wu, F., Mo, C., Liu, B., Zhu, J., Deng, Q., et al., 2011: Bioaccumulation of antimony, arsenic, and mercury in the vicinities of a large antimony mine, China. Microchem. J., 97, $12-19$.
17. Fu, Z., Wu, F., Mo, C., Deng, Q., Meng. W., Giesy, J. P., 2016: Comparison of arsenic and antimony biogeochemical behaviour in water, soil and tailings from Xikuangshan, China. Sci. Total Environ., 539, 97-104, DOI: 10.1016/j.scitotenv.2015.08.146.

18. Guo, W., Fu, Z., Wang, H., Liu, S., Wu, F., Giesy, J. P., 2018: Removal of antimonate $(\mathrm{Sb}(\mathrm{V}))$ and antimonite $(\mathrm{Sb}(\mathrm{III}))$ from aqueous solutions by coagulation-flocculation-sedimentation (CFS): Dependence on influencing factors and insights into removal mechanisms. Sci. Total Environ., 644, 1277-1285. DOI: 10.1016/j.scitotenv.2018.07.034.

19. Horáková, M., 2003: Water Analytics (In Czech), 1st edn., VŠCHT, Prague, 116-121.

20. Hrušková, T., 2014: The most important pollutants of Eastern Slovakia waters. J. Microbiol. Biotechnol. Food Sci., 4, 112-116. DOI: 10.15414/jmbfs.2014.4.2.112-116.

21. Hu, X., He, M., Li, S., Guo, X., 2017: The leaching characteristics and changes in the leached layer of antimony-bearing ores from China. J. Geochem. Explor., 176, 76-84. DOI: http://dx.doi.org/10.1016/j.gexplo.2016.01.009.

22. Hucko, P., 2012: Loading the Bukovec water-supply reservoir and the catchment area with arsenic and antimony. In Water Biology, Prague, CZ. Available online at http://archiv.ekomonitor.cz/sites/default/files/filepath/prezentace/21_hucko. pdf. Accessed on July 10, 2015.

23. Huy, T. B., Tuyet-Hanh, T. T., Johnston, R., Nguyen-Viet, H., 2014: Assessing health risk due to exposure to arsenic in drinking water in Hanam province, Vietnam. Int. J. Environ. Res. Public Health, 11, 7575-7591. DOI: 10.3390/ijerph 110807575.

24. Ilavský, J., Barloková, D., Munka, K., 2014: Antimony removal from water by adsorption to iron-based sorption materials. Water, Air, Soil Poll., 226, 1, 2238-2238. DOI: 10.1007/ s11270-014-2238-9

25. Kelepertsis, A., Alexakis, D., Skordas, K., 2006: Arsenic, antimony and other toxic elements in the drinking water of Eastern Thessaly in Greece and its possible effects on human health. Environ. Geol., 50, 76-84. DOI: 10.1007/s00254-0060188-2.

26. Khan, M. W., Khalid, M., Ullah, H., Rehman, H. U., Ayaz, Y., Ullah, F., et al., 2017: Detection of arsenic (As), antimony (Sb) and bacterial contamination in drinking water. Biol. Forum-Int. J., 9, 133-138.

27. Lešková, A., Molnárová, M., Fargašová, A., 2012: Biochemical view on the intake, metabolism and toxic effects of arsenic compounds on plants. Chem. Listy, 106, 1110-1115. 
28. Li, J., Wei, Y., Zhao, L., Zhang, J., Shangguan, Y., Li, F., Hou, H., 2014: Bioaccessibility of antimony and arsenic in highly polluted soils of the mine area and health risk assessment associated with oral ingestion exposure. Ecotox. Environ. Safe., 110, 308-315. DOI: 10.1016/j.ecoenv.2014.09.009.

29. Li, J., Zheng, B. H., He, Y., Zhou, Y., Chen, X., Ruan, S., et al., 2018: Antimony contamination, consequences and removal techniques: A review. Ecotox. Environ. Safe., 156, 125-134. DOI: 10.1016/j.ecoenv.2018.03.024.

30. Lieskovská, Z., Lényiová, P., et al., (Ed.), 2018: Report on the State of the Environment in SR in 2018 (In Slovak), MŽP and SAŽP, Slovakia, 222 pp.

31. Liu, F., Le, X. C., McKnight-Whitford, A., Xia, Z., Wu, F., Elswick, E., et al., 2010: Antimony speciation and contamination of waters in the Xikuangshan antimony mining and smelting area, China. Environ. Geochem. Health, 32, 5, 401413. DOI: $10.1007 /$ s10653-010-9284-z.

32. Matilainen, A. M., Gjessing, E. T., Lahtinen, Hed, L., Bhatnagar, A., Sillanpää, M., 2011: An overview of the methods used in the characterisation of natural organic matter (NOM) in relation to drinking water treatment. Chemosphere, 83, 11, 1431-1442. DOI: 10.1016/j.chemosphere.2011.01.018.

33. Murphy, K. R., Stedmon, C. A., Graeber, D., Bro, R., 2013: Fluorescence spectroscopy and multi-way techniques. Parafac. Anal. Methods, 5, 6557-6566.

34. Rapant, S., Dietzová, Z., Cicmanová, S., 2006: Environmental and health risk assessment in abandoned mining area, Zlatá Idka, Slovakia. Environ. Geol., 51, 3, 387-397. DOI: 10.1007/s00254-006-0334-x.

35. Rapant, S., Cvečková, V., Dietzová, Z., Fajčíková, K., Letkovičová, M., Sedláková, D., 2011a: The impact of geological environment on health status of residents of the Slovak Republic. Mineralica Slovaca, 43, 437-448.

36. Rapant, S., Fajčíková, K., Khun, M., Cvečková, V., 2011b: Application of health risk assessment method for geological environment at national and regional scales. Environ. Earth Sci., 64, 513-521. DOI: 10.1007/s12665-010-0875-x.

37. Regulation of the government of the SR No. 269/2010 Coll. which stipulates criteria for achieving good water balance. Effective of January 1, 2011.

38. Regulation of the government of the SR No. 496/2010 Coll. amending and supplementing the SR governmental regulation No. 354/2006 Coll. which determines requirements on water intended for human consumption and control of water intended for human consumption. Effective of January 1 , 2011.
39. Šestinová, O., Findoráková, L., Hančulák, J., Šestinová, D., 2015: Study of metal mobility and phytotoxicity in bottom sediments that have been influenced by former mining activities in Eastern Slovakia. Environ. Earth Sci., 74, 6017-6025. DOI: $10.1007 / \mathrm{s} 12665-015-4625-y$.

40. STN EN ISO 8467, 1993: Water quality. Determination of permanganate index (In Slovak). Publication date 1993-06.

41. STN EN ISO 6222, 1999: Water quality. Enumeration of culturable micro-organisms. Colony count inoculation in a nutrient agar culture medium (In Slovak). Publication date 1999-05.

42. STN EN ISO 7899-2, 2000: Water quality. Detection and enumeration of intestinal enterococci. Part 2: Membrane filtration method (In Slovak). Publication date 2000-04.

43. STN EN ISO 9297, 2000: Water quality. Determination of chloride. Silver nitrate titration with chromate indicator (Mohr's method) (In Slovak). Publication date 2000-08.

44. STN EN ISO 15 586, 2004: Water quality, determination of trace elements using atomic absorption spectrometry with graphite furnace (In Slovak). Publication date 2004-10.

45. STN EN ISO 10523, 2012: Water quality-Determination of pH (In Slovak). Publication date 2012-06.

46. STN EN ISO 9308-1, 2015: Water quality. Enumeration of Escherichia coli and coliform bacteria. Part 1: Membrane filtration method for waters with low bacterial background flora (In Slovak). Publication date 2015-10.

47. Sundar, S., Chakravarty, J., 2010: Review. Antimony toxicity. Int. J. Environ. Res. Public Health, 7, 4267-4277. DOI: 10. 3390/ijerph7124267.

48. Ursínyová, M., 2011: Risk Assessment of Arsenic Intake from Food and Water in the SR (In Slovak). Ministry of Agriculture and Rural Development. Available at http://www.mpsr.sk/ sk/index.php?navID=525\&navID2=525\&sID $=111 \& \mathrm{id}=5123$ $61 \mathrm{s.}$

49. US Environmental Protection Agency (USEPA) 816-F-090004, 2009: National Primary Drinking Water Standards and National Secondary Drinking Water Standards. EPA's Office of Water, Washington, D. C. Available at https://safewater. zendesk.com/hc/en-us/articles/212077917-4-What-are-EP A-s-drinking-water-regulations-for-antimony-. Accessed in April, 2017.

50. Vaclavikova, M., Gallios, G. P., Hredzak, S., Jakabsky, S., 2008: Removal of arsenic from water streams: an overview of available techniques. Clean Technol. Environ. Policy, 10, 89-95. DOI: 10.1007/s10098-007-0098-3.

51. Vojteková, V., Poperníková, Z., Ashraf, M., Abusenaina, 
M., 2014: Antimony in various environment elements (In Slovak). Chem. Listy, 108, 135-140.

52. WHO, 1996: World Health Organization and International Programme on Chemical Safety. Guidelines for Drinking-Water Quality. Vol. 2, Health Criteria and Other Supporting Information, 2nd edn., Available at https://apps.who.int/iris/ handle/10665/38551.

53. WHO, 2008: Guidelines for Drinking-water Quality (3rd. ed.). Vol. 1, Recommendations, 3rd edn., Geneva, WEB version, 515 pp.

54. Wilson, S. C., Lockwood, P. V., Ashley, P. M., Tighe, M., 2010: The chemistry and behaviour of antimony in the soil environment with comparisons to arsenic: A critical review. Environ. Poll., 158, 1169-1181.
55. Wu, F., Fu, Z., Liu, B., Mo, C., Chen, B., Corns, W., Liao, H., 2011: Health risk associated with dietary co-exposure to high levels of antimony and arsenic in the world's largest antimony mine area. Sci. Total Environ., 409, 3344-3351.

56. Yang, H., He, M., Wang, X., 2015: Concentration and speciation of antimony and arsenic in soil profiles around the world's largest antimony metallurgical area in China. Environ. Geochem. Health, 37, 21-33. DOI: 10.1007/s10653-014-9627-2.

57. Zhang, H., Cui, K., Guo, Z., Li, X., Chen, J., Qi, Z., Xu, S., 2020: Spatiotemporal variations of spectral characteristics of dissolved organic matter in river flowing into a key drinking water source in China. Sci. Total Environ., 700, 134360. DOI: 10.1016/j.scitotenv.2019.134360.

Received June 22, 2020

Accepted August 18, 2020 